\title{
CARTA AOS LEITORES
}

Para atender o seu variado público, os Cadernos Prolam/USP - Brazilian Journal of Latin American Studies - publicam sua edição de número 25, com temáticas variadas dentro dos estudos latino-americanos. Com um espectro temático que vai das Relações Internacionais à Comunicação Social, nossa revista enfatiza a interdisciplinaridade e a perspectiva comparada como caminhos para a excelência acadêmica. Tem sido nossa preocupação, nestes doze anos de percurso, desenvolver um periódico de estudos avançados, que consiga dar suporte para a Política Pública, dentro daquelas esferas de necessidades que são próprias dos países da América Latina.

No nosso primeiro artigo, Alejandro Simonoff apresenta um quadro tipológico das teorias das relações internacionais elaboradas no Cone Sul entre os fins de 1960 e começo de 1980. O artigo trata das teorias autonomistas de Linck e O’Donnell, Hélio Jaguaribe, Juan Carlos Puig e Luciano Tomasini. Tais autores contribuem para a construção do pensamento latino-americano nas relações internacionais, mas também por apresentarem novidades do ponto de vista epistemológico. Cada um desses pensadores consegue mesclar princípios do pensamento econômico da CEPAL com elementos da escola realista das Relações Internacionais. Trata-se de um debate complexo que o professor Simonoff conduz com maestria.

Lívia Semensato Sacchetti e Alex Luiz Ferreira apresentam um importante estudo sobre o nível de integração econômica entre os Estados-membros do Mercosul. Trata-se de um trabalho sobre integração econômica, que faz uso da análise das séries de tempo dos diferenciais de taxa de juros reais das economias da Argentina, do Brasil, do Uruguai e do Paraguai, no período compreendido entre julho de 1995 e setembro de 2011.

Outro trabalho interessante sobre o Mercosul é o apresentado por Rita de Cássia Marques Lima de Castro. O artigo analisa a possibilidade de integração dos países do Mercosul por meio da educação superior universitária. A autora retoma diversos pontos e fases do processo de construção do Mercosul e faz a análise de documentos particulares à integração do setor educacional. Fora isso, a autora fez uso de questionários aplicados via web, e chegou a conclusões significativas a respeito do papel do Setor Educacional do Mercosul (SEM).

Um trabalho de natureza metodológica é apresentado pelo professor Jesús Porras Serrano. Fazendo uso do conceito de Economias Baseadas no Conhecimento (EBC), Serrano propõe um método de avaliação da efetividade das políticas públicas neste setor. $\mathrm{O}$ México é usado como exemplo, mas a metodologia é proposta para todas as economias da América Latina. Trata-se de um assunto novo e ainda pouco abordado, sendo que o artigo do professor Serrano constitui uma relevante contribuição para o nosso periódico.

Dirceu Yoshikazu Teruya nos traz uma interessante discussão sobre o Direito da Propriedade Intelectual nos países da América Latina. O direito à propriedade intelectual 
tem sido um importante item da pauta de negociações no contexto do Acordo Geral sobre Tarifas do Comércio (GATT) desde a Rodada Uruguai (1986-1994). No artigo, Teruya discute a expressividade da produção de patentes pelas economias latino-americanas, bem como os fatores que influenciam nesta realidade.

Um excelente trabalho de autoria de José Alfredo Uribe Salas e María Teresa Cortés Zavala traz a história da institucionalização da ciência geológica no México. São discutidas a atuação e a importância dos pais fundadores das Geociências no México entre os séculos XVIII e XIX. Tais intelectuais foram Andrés Manuel del Río, Antonio del Castillo e José G. Aguilera, que agora são retomados neste artigo que muito tem a contribuir para os interessados na História da Ciência.

Cobrindo o flanco de políticas territoriais, Vitor Hélio Pereira de Souza e Márcio Rogério Silveira discutem a atual política conjunta de implantação de infraestrutura na América do Sul. Trata-se de um trabalho analítico sobre a Iniciativa para a Integração Física da América do Sul (IIRSA). O trabalho descreve a arquitetura institucional do empreendimento bem como os eixos de integração física que atualmente são implantados para prover as economias sul-americanas de meios logísticos.

Armando Gallo Yahn Filho faz a análise da política internacional na Bacia do Rio da Prata durante as décadas de 1960 e 1970. Essas décadas representam uma mudança significativa dos rumos da política externa tanto da Argentina quanto do Brasil, uma vez que o tratado tripartite de 1979 inaugurou uma fase de cooperação mais efetiva entre os grandes Estados da Bacia, o que ofereceu os precedentes para a assinatura do Tratado de Assunção em 1991. O que Yahn Filho faz é debater e contextualizar os documentos anteriores ao tratado tripartite, deixando em evidência a causa da ineficiência da "Ata de Iguaçu” (1966), da "Declaração de Buenos Aires" (1967), da "Ata de Santa Cruz de la Sierra" (1968) e do Tratado da Bacia do Prata (1969). É uma leitura que vale a pena para aqueles interessados em revisitar as grandes questões da Geopolítica da Bacia do Rio da Prata.

Nosso nono artigo traz para o debate acadêmico a questão do Direito Constitucional dos povos indígenas. Félix Pablo Friggeri analisa, tanto do ponto de vista político quando do ponto de vista epistemológico, o chamado novo constitucionalismo latino-americano, que é uma dimensão importante da construção dos Estados plurinacionais da Bolívia e do Equador. Friggeri aponta para as necessidades epistemológicas que este empreendimento exige, principalmente no que toca à construção de uma nova ciência antropológica.

Na seção de resenhas, Margarida Nepomuceno resenha o livro de José Aparecido Rolon "Paraguai. Transição democrática e Política Externa" (Annablume, 2011). O livro explora características da política doméstica paraguaia que interfere em sua política externa. Temas importantes para o estudo do Paraguai são abordados no livro, como a carência histórica de democracia e estabilidade política, as relações com a Argentina, o Brasil e os EUA e os desafios e necessidades para a construção de um regime democrático a partir da década de 1990. Nepomuceno faz muito bem a síntese das ideias do livro em um texto de leitura fluida.

Como sempre, somos profundamente gratos aos nossos colaboradores - autores, pareceristas e membros do conselho científico - pela confiança e pelas contribuições 
prestadas para a manutenção da qualidade dos nossos artigos e resenhas. Agradecemos também aos nossos parceiros da Editora LTr e do Sistema Integrado de Bibliotecas da Universidade de São Paulo (SIBI/USP) pelo valoroso apoio prestado para garantir a qualidade acadêmica do nosso periódico.

Boa leitura!!

Profa. Dra. Maria Cristina Cacciamali - Editora dos Cadernos Prolam/USP Prof. Dr. Sedi Hirano - Presidente do Conselho Científico Me. Marcos Antônio Fávaro Martins - Editor Assistente Ana Sofia Garcia Salas - Editora Assistente. 